\title{
FEATURES OF TEACHING HUMANITIES IN HIGHER EDUCATION INSTITUTIONS FOR FUTURE SPECIALISTS IN HOTEL AND RESTAURANT BUSINESS AND TOURISM
}

\author{
Lesia Zelman ${ }^{1}$, Oleksandr Mykytenko ${ }^{2}$
}

Received: 2021-05-04

Accepted: 2021-07-08

DOI: http://doi.org/10.46489/gpj.2021-1-2-4

Abstract. We have considered the features of professional training of specialists in the hotel and restaurant business and tourism. In the analysis of the curriculum, we appear to find a place in the training of future specialists in hotel and restaurant business and tourism in the study of humanities, namely: "Ukrainian language for professional purposes", "World culture and art", "Foreign language for professional orientation", "Fundamentals of professional ethics and culture of communication", and other. During the course, participants of the educational process must make efforts to form a communicative culture, critical thinking and aesthetics of speech. Future masters of hotel and restaurant business and tourism must be at a high level of management of communicative culture and content to think critically. The humanities cycle subjects basing on the text, with the help of which educational activities are carried out, training of future specialists of hotel and restaurant enterprises and tourism takes part in professional texts that help students accumulate professional terminology and form professional skills. We concluded that introducing elements of the dual system of education is a positive trend in the training of hotel and restaurant professionals and tourism. Students can assimilate and improve communication culture, see bottlenecks and make an effort to correct and improve themselves.

Keywords: hotel and restaurant business, tourism, humanitarian subjects, communicative possibilities, professional text.

\footnotetext{
${ }^{1}$ Lesia Zelman, PhD in Pedagogical Science, Head of the Department of Social Sciences and Humanities, Lviv University of Business and Law, Kulparkivska str., 99, Lviv, Ukraine, ORCID: https://orcid.org/0000-0002-2497$7292 X$

2 Oleksandr Mykytenko, PhD student, Senior Lecturer, Department of Social Sciences and Humanities, Lviv University of Business and Law, Kulparkivska str., 99, Lviv, Ukraine, oleksandr.mykytenko.robota@gmail.com ORCID: https://orcid.org/0000-0002-5983-7548
} 


\section{ВСТУП}

Постійні зростанням вимог до професійної діяльності зумовлені динамічними змінами сучасності. Для фахівця сфери «людина-людина» як чинник успішної професійної діяльності $\epsilon$ формування професійної комунікативної культури. Розвиток комунікативних здібностей майбутніх фахівців готельно-ресторанної справи та туризму $€$ важливою складовою їх професійної підготовки, адже від уміння налагоджувати контакт, ефективно спілкуватися залежить продуктивність їх майбутньої професійної діяльності. Комунікативні здібності майбутніх фахівців формуються під час вивчення гуманітарних предметів. Такі навчальні предмети мають максимально працювати над формуванням професійних компетенцій. Питання професійної підготовки зазначених фахівців досліджені в публікаціях багатьох науковців: I. Babii, O. Dolhopol, S. Vdovych, O. Zamferesko, L. I. Matsko, L. M. Palamar, M. I. Pentyliuk, V. Poluda, L. Rudenko, O. M. Semenoh та ін. Незважаючи на значну кількість досліджень із вказаної теми, проблема формування комунікативної культури майбутніх фахівців у навчальних закладах під час вивчення дисциплін саме гуманітарного циклу є актуальною, це і зумовило вибір теми наукового дослідження. Актуальність теми зумовлена також і тим, що в сучасних умовах збільшилася кількість професій типу «людина - людина», які необхідні у багатьох сферах. Аналіз досліджень свідчить, що вивчення гуманітарних дисциплін формує професійні якості майбутніх фахівців готельноресторанної справи та туризму.

Мета статті - з'ясувати особливості викладання гуманітарних дисциплін для майбутніх фахівців готельноресторанної справи та туризму у вищих навчальних закладах.

\section{РЕЗУЛЬТАТИ}

У сучасних соціально-економічних умовах збільшилася кількість професій сфери обслуговування, які здійснюють діяльність у багатьох сферах: готельноресторанна справа, туризм побутове обслуговування, роздрібна торгівля, житлово-комунальне господарство, фінансові послуги, соціальне забезпечення населення, медичне обслуговування та ін. Професійна діяльність майбутнього фахівця - це не лише ставлення фахівця до об'єкта праці, а й стосунки зі співробітниками та клієнтами. У професіях типу «людина - людина» вимоги до працівників значно зростають, від них вимагається не лише висока кваліфікація, але і глибоке усвідомлення свого морального обов'язку перед людьми. Основне завдання майбутнього фахівця - якісне надання послуг, тому, крім професійних аспектів, варто значну увагу приділити формуванню особистісних якостей фахівця а саме: пунктуальності, тактовності, дисциплінованості, працелюбності, ініціативності, комунікативність, чесності, порядності та ін.

Сьогодні випускники закладів, вступаючи в самостійне життя, відчувають на собі труднощі формування чітко визначених життєвих орієнтирів та суттєву розбіжність між змістом життя i змістом того, чого навчалися, тому сучасна парадигма освіти, на думку В. Кудіна (Osvitni paradyhmy suchasnosti, n.d.), повинна спиратися на такі принципові тези:

1. Освіта за своїм змістом і метою єдина для всіх, як єдині відкриття науки. Освіта має бути наукоємкою.

2. Пропоновані системою освіти вимоги, їх об'єднані для всіх країн i народів, вони обумовлюють потребу в створенні загальнопланетарного педагогічного простору, заснованого на необмеженому прагненні до 
досконалості і розширенню меж пізнання.

3. Освіта має спиратися на наукову і культурну основу розвитку особистості, сприяти формуванню людини 3 інноваційним типом мислення, культури i поведінки, здатної розвиватися самостійно в контексті зростаючого об'єму інформації.

4. Творче застосування отриманих знань, втілення їх у практичній діяльності 3 усвідомленням максимальної відповідальності за наслідки своїх дій та вчинків.

5. Освіта має бути джерелом радості і задоволення для тих хто навчає та тих кого навчають.

Підготовка майбутніх фахівців готельно-ресторанної справи та туризму потребує вдосконалення технологій навчання та «приведення завдань професійно-комунікативної підготовки у відповідність до вимог культурологічно, синергетично й особистісно орієнтованої нової освітньої парадигми задля формування комунікативної культури, яка визначає конкурентоспроможність випускників закладів на ринку праці» (Rudenko L. A.,

Таким чином, аналізуючи вищесказане, зазначимо, що сучасні навчальні заклади мають підготувати сьогоднішнього студента до успішної професійної діяльності, заклади освіти покликані не просто дати студентам суму знань, умінь i навичок, a формувати в них компетентність як загальну здатність, що грунтується на знаннях, досвіді, цінностях, здібностях, отриманих завдяки навчанню. Студенти повинні на високому рівні володіти власне професійною діяльністю в обраній галузі; вміти проектувати свій подальший професійний розвиток; володіти навичками морально-правової відповідальності за якість і результати своєї праці.

$\begin{array}{llr}\text { Професійні } & \text { якості } & \text { фахівця } \\ \text { грунтуються } & \text { на } & \text { знаннях }\end{array}$

фундаментальних, професійно орієнтованих i гуманітарних наук, уміннях i навичках виконувати професійні обов'язки. Навчальні предмети, які вивчають студенти під час навчання у вищому навчальному закладі, мають максимально працювати над формуванням професійних компетенцій. Важливий вплив на формування особистості студента відіграють гуманітарні предмети, вивчення яких в навчальному закладі допоможе студентам виробити та вдосконалити свої професійні якості, які згодом допоможуть їм реалізувати себе як фахівця. Тому вважаємо, що предмети гуманітарного циклу займають вагому нішу в новітній освітній парадигмі, адже розвивають в студентів передусім комунікативні здібності та творчу уяву. Результатом комунікативної підготовки має стати готовність студента до професійного спілкування - багатопланового складного процесу налагодження i розвитку контактів між людьми у процесі професійної діяльності, в результаті якого здійснюється взаємовплив особистостей, обмін між ними інформацією та вироблення загальної стратегії взаємодії, сприйняття, розуміння. Важливе значення має і естетика мовлення, яку студенти черпають під час читання творів, різноманітних текстів, а на заняттях вчаться правильно аналізувати прочитане та висловлювати свою думку. Естетика мовлення тісно пов'язана 3 естетикою діяльності особистості фахівця, який повинен прагнути бачити красу в кожній людині, у будь-якій діяльності та в навколишньому середовищі. Від безпосередності та щирості такого прагнення буде залежати ефективність його спілкування, а отже, і професійної діяльності (Vdovych, S. М., 2012). Ці ознаки свідчать про культуру мовлення особистості, яку студенти вдосконалюють на заняттях 
гуманітарних дисциплін. Вивчення предметів гуманітарного циклу у вищих навчальних закладах дозволяє розвивати не тільки комунікативні здібності, а у готує студентів готельноресторанної справи та туризму до самостійної творчої діяльності. Велике значення має розвиток творчості, адже саме люди 3 творчим мисленням приносять у життя щось нове. Такі люди найчастіше стають лідерами. Творчість має вирішальне значення в розвитку здібностей людини, формуванні їі активної життєвої позиції.

Зазначимо, що 13 січня 2010 р. № 85-р схвалено розпорядженням Кабінет Міністрів України Концепцію проекту Закону України «Про основні засади державної комунікативної політики», де зазначається, що виховання нового покоління має спрямовуватись на формування в людей комунікативної культури (Kontseptsiia proektu Zakonu Ukrainy «Pro Osnovni zasady derzhavnoi komunikatyvnoi polityky»).

На сьогодні уже сформована нормативно-правова база, відповідно до якої здійснюється професійна підготовка фахівців готельноресторанної справи та туризму. При аналізі навчальних програм 3'ясовано, що важливе місце у підготовці майбутніх фахівців готельноресторанної справи та туризму належить вивченню предметів гуманітарного циклу. Проаналізуємо дещо детальніше особливості вивчення предметів гуманітарного циклу $\mathrm{y}$ вищому навчальному закладі. Це доцільно здійснювати під час суспільногуманітарної підготовки при вивченні предметів «Українська мова за професійним спрямуванням», «Світова культура та мистецтво», «Іноземна мова за професійним спрямуванням», «Основи професійної етики та культури спілкування» та ін. Вивчення предметів гуманітарного циклу в навчальному закладі допоможе студентам виробити та вдосконалити свої комунікативні здібності, які згодом допоможуть їм реалізувати себе як фахівця, адже спілкування має важливе значення для досягнення успіху в професійній діяльності.

В основі предметів гуманітарного циклу лежить текст (художні, науковий), за допомогою якого відбуваються навчальні дії. При вивченні предметів гуманітарного циклу навчальний текст виконує низку дидактичних функцій:

1) пізнавальну: спостереження й осмислення виучуваного лексико-граматичного матеріалу; б) джерело нової мовної інформації; в) матеріал для створення проблемних завдань;

2) навчальну: а) формує й розвиває комунікативні навички; б) слугує зразком мовленнєвої культури, правильності усного й писемного мовлення; в) демонструє стилістичну варіативність мовлення та функціонування різнорівневих мовних одиниць у межах певного функційного стилю;

3) розвивальну: а) розвиває мовні/мовленнєві здібності учнів; б) розвиває комунікативну компетенцію; в) розвиває мовленнєву ініціативу;

4) комунікативну: а) спонукає учнів до мовленнєвого спілкування; б) $\epsilon$ джерелом навчального діалогу/полілогу між учителем i учнями; в) $\epsilon$ зразком моделювання ситуацій спілкування (Babii I. V., 2015).

Як бачимо, комунікативні здібності майбутніх фахівців формуються під час вивчення гуманітарних предметів, тому основне завдання гуманітарних дисциплін забезпечити розвиток та формування професійної комунікації. При виборі тексту на заняття для підготовки майбутніх фахівців готельно-ресторанної справи та туризму важливо здійснювати на основі фахових текстів. «Робота із правильно дібраними й системно організованими 
текстами дозволяє формувати окремі мовні поняття, демонструвати взаємодію всіх мовних засобів (фонетичних, лексичних, граматичних), забезпечує формування комунікативних умінь і навичок, а також $\epsilon$ одним із засобів управління мотивацією учнів під час організації мовленнєвої діяльності» (Babii I. V., 2015). Є. Кулькіна зазначає, що фахові тексти за спеціальністю вважаються не лише основним джерелом для накопичення фахової термінології, але й засобом становлення й розвитку професійної майстерності та професійно орієнтованої ерудиції (Kulkina Ye. A., 2007).

На заняттях при аналізі текстів студенти вчаться мислити, ставити продумані запитання, зіставляти факти й аналізувати свої думки. Студенти уважно мають слухати опонента, щоб оцінити його висловлювання та сформулювати логічні запитання - усе це створює можливості для формування навичок критичного мислення, які пов'язані 3 умінням добувати, опрацьовувати та використовувати інформацію $з$ різних джерел, а також викладати результати ї̈ аналізу в стислій формі. Таким чином, студенти охоплені активною творчою навчальною діяльністю на заняттях, залучені до процесу самонавчання, самореалізації, вчаться спілкуватися, співпрацювати, критично мислити, обстоювати свою позицію. Формування навичок критичного мислення конкурентноздатність і мобільність освіченої людини на ринку праці, їі готовність жити і працювати в умовах неперервних змін. Критичне мислення це процес, який найчастіше починається 3 постановки проблеми, продовжується пошуком i осмисленням інформації. Закінчується такий процес прийняттям рішенням щодо розв'язання поставленої проблеми (Vykorystannia tekhnolohii krytychnoho myslennia yak zasobu stvorennia tvorchoho mikroklimatu na urotsi svitovoi literatury, n.d).
Babii I. V. (2015) виділяє такі критерії відбору

навчального текстового матеріалу, що сприятимуть формуванню відповідних компетенцій у майбутніх фахівців сфери обслуговування:

1. Інформаційний. Текст знайомить учнів із новою інформацією, що стимулює їхню інтелектуальнопізнавальну діяльність.

2. Методичний. Відібраний текстовий матеріал повинен бути придатним для створення на його основі системи мовних, мовленнєвих і комунікативних вправ і завдань. Зазначено, що саме цей критерій повинен бути основним у відборі текстів для навчальних потреб.

3. Лінгвістичний. Тексти повинні давати студентам повне уявлення про функційні стилі сучасної української мови, бути насиченими комунікативно значущою лексикою, граматичними конструкціями, що розширюватиме словниковий запас, ілюструватиме відповідні мовні явища.

4. Комунікативний. Комунікативні вміння й навички формуються засобами навчального тексту та системи післятекстових вправ і завдань.

5. Виховний. Текстовий матеріал $\epsilon$ основним засобом реалізації виховних можливостей предмета «Українська мова», що дозволяє залучити учасників до духовної культури українського народу, розширити їх світоглядні обрії, сприяє формуванню свідомої мовної особистості, що можливо за умов використання найрізноманітніших за змістом і стилем текстів.

6. Критерій доступності відповідає одному із загальнодидактичних принципів й передбачає, що текстовий навчальний матеріал повинен бути доступним учням, а саме враховувати їх вікові особливості, рівень мовної підготовки, когнітивного розвитку [2, c. 88]. 


\section{ВИСНОВКИ}

Важливо зазначити, що на сучасному етапі відбувається впроваджується дуальної системи навчання. Це навчання, яке відбувається в навчальному закладі та паралельно на виробництві. Мета впровадження дуальної системи навчання збалансувати запити роботодавців 3 пропозиціями, які пропонують навчальні заклади, а це надасть можливості закладам освіти враховувати вимоги роботодавців та мобільно реагувати на зміни в потребах ринку праці. Упровадження дуальної системи навчання передбачає, що $70 \%$ практичної підготовки майбутнього

\section{References}

Babii I. V. (2015). Pedahohichni umovy rozvytku profesiinoho movlennia uchniv profesiino-tekhnichnykh navchalnykh zakladiv sfery obsluhovuvannia: dys. kand. ped. nauk: 13.00.04. $245 \mathrm{~s}$.

Kontseptsiia proektu Zakonu Ukrainy «Pro Osnovni zasady derzhavnoi komunikatyvnoi polityky». Retrieved from http://zakon2.rada.gov.ua/laws/show/852010-\%D1\%80.

Kulkina Ye. A. (2007). Pryiomy roboty $\mathrm{z}$ navchalnymy tekstamy $\mathrm{z}$ anhliiskoi movy na peredtekstovomu etapi. Inozemni movy v shkoli. No 5. P. 44.

Osvitni paradyhmy suchasnosti (n.d.). Retrieved from https://studopedia.su/16_148949_osvitniparadigmi-suchasnosti.html

Rudenko L. A. (2015). Formuvannia komunikatyvnoi kultury maibutnikh fakhivtsiv sfery obsluhovuvannia $u$ profesiino-tekhnichnykh navchalnykh zakladakh: monohrafiia. Lviv: Piramida. $343 \mathrm{~s}$.

Vdovych, S. M. (2012). Shliakhy vdoskonalennia movnoi pidhotovky uchniv PTNZ iz vykorystanniam suchasnykh osvitnikh tekhnolohii. Humanitarna osvita i potreby rynku pratsi: monohrafiia, za red. H. P. Vasianovycha, S. M. Vdovych. Kyiv : Pedahohichna dumka. S. 85-106. фахівця проходитиме безпосередньо на виробництва, а на теоретичні заняття планується до 30\%. Такі умови дозволять студенту оцінити рівень комунікативної культури та мати можливість їі виправити та вдосконалити.

Таким чином, сучасна освіта має підготувати фахівця готельноресторанної справи та туризму, який зуміє реалізувати свої професійні здібності в сучасному суспільстві, тому предмети гуманітарного циклу беруть активну участь у формування такої особистості, а отже, займають важливе місце в освітній парадигмі.

Vykorystannia tekhnolohii krytychnoho myslennia yak zasobu stvorennia tvorchoho mikroklimatu na urotsi svitovoi literatury. (n.d). Retrieved from http://oin.in.ua/vykorystannyatehnolohiji-krytychnoho-myslennya-yakzasobu-stvorennya-tvorchohomikroklimatu-na-urotsi-svitovojiliteratury/

Zelman L. N. (2017). Pidhotovka kvalifikovanykh robitnykiv sfery obsluhovuvannia $\mathrm{u}$ profesiinotekhnichnykh navchalnykh zakladakh Ukrainy (1969 r. - pochatok KhKhI stolittia): dys. kand. ped. nauk: 13.00.04 / Zelman Lesia Nestorivna; Lvivskyi derzhavnyi universytet bezpeky zhyttiediialnosti. L.,. $276 \mathrm{~s}$. 